\title{
Gender-based Abuse: The Global Epidemic ${ }^{1}$ Violência e Genêro: Uma Epidemia Global
}

\author{
Lori Heise $^{2}$
}

HEISE, L. Gender-based Abuse: The Global Epidemic. Cad. Saúde Públ., Rio de Janeiro, 10 (supplement 1): 135-145, 1994.

Gender Based violence-including rape, domestic violence, murder and sexual abuse-is a profund health problem for women across the globe. Although a significant cause of female morbidity and mortality, violence against women has only recently begun to be recognized as an issue for public health. This paper draws together existing data on the dimensions of violence against women worldwide and reviews available literature on the health consequences of abuse. It argues that the health sector has an important role to play in combatting violence against women through increased research, screening and referral of victims, and behavioral interventions. Any strategy to confrnt violence must address the root causes of abuse in addition to meeting the immediate needs of victims. This means challenging the social attitudes and beliefs that undergird men's violence and renegotiating the balance of power between women and men at all levels of society.

Key words: Violence and Women; Reproductive Health; Sexual Abuse; International Development

\section{INTRODUCTION}

Gender-based violence - including rape, domestic violence, mutilation, murder, and sexual abuse - is a profound health problem for women across the globe. Although a significant cause of female morbidity and mortality, gender violence is almost never seen as a public health issue. Recent World Bank estimates of the global burden of disease indicate that in Established Market Economies, gender-based victimization is responsible for one out of every five healthy days of life lost to women of reproductive age. On a per capita basis, the health burden imposed by rape and domestic violence is roughly equivalent in both the industrial and developing world, but because the overall burden is so much greater in the developing

\footnotetext{
${ }^{1}$ Part of the research for this article was pursued under contract with the United Nation's Statistical Office and the World Bank. Additional support was provided by the Ford Foundation.

2 Pacific Institute for Women's Health 1730 Rhode Island Ave. NW, Suite 712, Washington D. C. 20036.
}

world, the percentage attributable to genderbased victimization is smaller (World Bank, 1993). Nonetheless, on a global basis, the health burden among reproductive age women of gender-based victimization is comparable to that posed by other conditions already high on the world agenda (Table 1).

Female-focused violence also represents a hidden obstacle to economic and social development. By sapping women's energy, undermining their confidence, and compromising their health, gender violence deprives society of women's full participation. As the United Nations Fund for Women (UNIFEM) recently observed, "Women cannot lend their labor or creative ideas fully if they are burdened with the physical and psychological scars of abuse"(Carrillo, 1992).

In recent years, the world community has taken some tentative, yet important, steps toward urging greater attention to the issue of gender-based abuse. Various United Nations bodies, including the General Assembly (Resolution 48/104), the Economic and Social Council, and the Committee on Crime Prevention and Control, have all passed 
resolutions recognizing violence against women as an issue of grave concern. Negotiations are also underway through the Organization of American States to draft a Pan American Treaty Against Violence Against Women.

This international attention, however, comes on the heels of over two decades of organizing by women's groups around the world to combat gender-based abuse. In country after country, women have started crisis centers, passed laws, and worked to change the cultural beliefs and attitudes that undergird men's violence. A recent directory published by the Santiago-based ISIS International, lists 379 separate organizations working against gender violence in latin America alone (ISIS, 1990).

TABLE 1. Estimated Health Burden of Various Conditions for Women Aged 15 To 44 , Globally

\begin{tabular}{lc}
\hline \hline & $\begin{array}{c}\text { DALYS } \\
\text { (in } \\
\text { millions) }\end{array}$ \\
\hline Maternal Conditions & 29.0 \\
STDs excluding HIV & 15.8 \\
Tuberculosis & 10.9 \\
HIV & 10.6 \\
Cardiovascular Disease & 10.5 \\
Rape and Domestic Violence & b \\
All Cancers & 9.5 \\
Motor Vehicle Accidents & 9.0 \\
War & 4.2 \\
Malaria & 2.7 \\
\hline \hline
\end{tabular}

DALY (Disability Adjusted Life Year) = a measure of healthy years of life lost due to health-related morbidity or premature death. Every year lost to death is counted as 1 DALY and every year spent sick or incapacitated is counted as a fraction of a DALY, based on the severity of the disability. Four further explanation see (World Bank, 1993).

b Rape and domestic violence, which are included in this table for illustrative purposes, are risk factors for disease conditions, such as STDs, depression, and injuries. They are not diseases in and of themselves.

\section{THE MAGNITUDE OF THE PROBLEM}

Gender-based violence includes a host of harmful behaviors that are directed at women and girls because of their sex, including wife abuse, sexual assault, dowry-related murder, marital rape, selective malnourishment of female children, forced prostitution, female genital mutilation, and sexual abuse of female children. Specifically, violence against women includes any act of verbal or physical force, coercion or life-threatening deprivation, directed at an individual woman or girl that causes physical or psychological harm, humiliation, or arbitrary deprivation of liberty and that perpetuates female subordination (Heise et al., 1994).

\section{Domestic Violence}

The most pervasive form of gender violence is abuse of women by intimate male partners. Over 30 well-designed surveys are now available from a wide range of countries showing that between one-fifth to over half of women interviewed have been beaten by a male partner (Table 2). The majority of these women are beaten at least three times a year with many experiencing persistent psychological and sexual abuse as well.

According to a recent review in the Journal of the American Medical Association, "Women in the United States are more likely to be assaulted and injured, raped or killed by a current or ex-male partner than all other assailants combined' (American Medical Association, 1992). The same could be said of women elsewhere in the world. In Papua New Guinea, 18 percent of all urban wives surveyed had received hospital treatment for injuries inflicted by their husbands (Toft, 1986). In Alexandria, Egypt, domestic violence is the leading cause of injury to women, accounting for 28 percent of all visits to area trauma units (Graitcer, 1994). And in countries as diverse as Brazil, Israel, Canada, and Papua New Guinea, over half of all women murdered are killed by a current or former partner (Heise et al., 1994). 
TABLE 2. Prevalence of Wife Abuse, Selected Countries

\begin{tabular}{|c|c|c|}
\hline Country, Year (ref. no.) & Sample Size and Type & Findings: Comments \\
\hline Barbados, 1993 (1) & $\begin{array}{l}\text { island-wide national probability } \\
\text { sample; } 264 \text { women and } 243 \text { men } \\
\text { aged } 20-45\end{array}$ & $\begin{array}{l}30 \% \text { of women battered as adults; women and men } \\
\text { report } 50 \% \text { of their mothers beaten }\end{array}$ \\
\hline Antigua, 1993 (2) & $\begin{array}{l}\text { random subset of national probability } \\
\text { sample; } 97 \text { women aged } 20-45\end{array}$ & $\begin{array}{l}30 \% \text { of women battered as adults; women and men } \\
\text { report that } 50 \% \text { of mothers beaten }\end{array}$ \\
\hline Uganda, 1991 (3) & $\begin{array}{l}\text { house to house written survey; } 16 \\
\text { women from each of Kampala's five } \\
\text { division (i.e. } 80 \text { in all) }\end{array}$ & $\begin{array}{l}46 \% \text { of women responding }(\mathrm{n}=73) \text { reported being } \\
\text { physically abused by a partner; additional } 7 \\
\text { women reported beatings by family members and } \\
\text { another } 5 \text { assaults or rapes by outsiders }\end{array}$ \\
\hline Kenya, 1990 (4) & $\begin{array}{l}\text { district-wide cluster sample from } \\
\text { contraceptive prevalence survey; } 733 \\
\text { women from Kissi District }\end{array}$ & $42 \%$ "beaten regularly" \\
\hline Tanzania, 1990 (5) & $\begin{array}{l}\text { convenience sample from Ilala, } \\
\text { Temeke and Kinondoni districts; } 300 \\
\text { women from Dar es Salaam }\end{array}$ & $60 \%$ had been "physically abused" by a partner \\
\hline Zambia, 1992 (6) & $\begin{array}{l}\text { convenience sample of women from } \\
\text { shanty compounds, medium and high } \\
\text { density suburbs of Lusaka and Kafue } \\
\text { Rural; } 171 \text { women aged } 20-40\end{array}$ & $\begin{array}{l}40 \% \text { "beaten" by a partner; another } 40 \% \text { "mentally } \\
\text { abused"; } 17 \% \text { considered physical or mental abuse } \\
\text { a normal part of marriage }\end{array}$ \\
\hline $\begin{array}{l}\text { Papua New Guinea } \\
1987 \text { (7) }\end{array}$ & $\begin{array}{l}\text { rural survey in } 19 \text { villages in all } \\
\text { regions and provinces ( } 736 \text { men; } 715 \\
\text { women); urban survey with } \\
\text { oversample of elites ( low income: } \\
368 \text { men; } 298 \text { women; elite: } 178 \text { men; } \\
99 \text { women) }\end{array}$ & $\begin{array}{l}67 \% \text { rural, } 56 \% \text { low income urban and } 62 \% \text { elite } \\
\text { urban women "beaten"; good agreement between } \\
\text { percent of women who claim to have been beaten } \\
\text { and percent of men who admit to abuse }\end{array}$ \\
\hline Sri Lanka, 1990 (8) & $\begin{array}{l}\text { convenience sample from low income } \\
\text { neighborhood of Colombo; } 200 \\
\text { mixed ethnic women }\end{array}$ & $\begin{array}{l}60 \% \text { had been beaten; } 51 \% \text { of those beaten said } \\
\text { husbands used weapons }\end{array}$ \\
\hline Korea, 1992 (9) & $\begin{array}{l}\text { three-stage, stratified random sample } \\
\text { of entire country; face to face } \\
\text { interviews with } 707 \text { women and } 609 \\
\text { men who had lived with a partner for } \\
\text { at least two years }\end{array}$ & $\begin{array}{l}37.5 \% \text { of wives reported "being battered" by } \\
\text { spouse in last year; } 12 \% \text { reported serious physical } \\
\text { abuse in last year ( } \mathrm{N} \text { to } \mathrm{R} \text { on CTS scale) }\end{array}$ \\
\hline Korea, 1988 (10) & $\begin{array}{l}\text { convenience sample; based on } \\
\text { distributed questionnaires, } 708 \\
\text { women in Suwon and Seoul } \\
\end{array}$ & $\begin{array}{l}42 \% \text { had been "beaten by husband after marriage"; } \\
14 \% \text { reported being "beaten by their husband" } \\
\text { within the last year }\end{array}$ \\
\hline India, 1993 (11) & $\begin{array}{l}100 \% \text { sample of potter community in } \\
\text { each village based on previous } \\
\text { census; } 170 \text { women of childbearing } \\
\text { age in } 3 \text { villages in rural southern } \\
\text { Karnataka }\end{array}$ & $\begin{array}{l}22 \% \text { of women reported being "physically } \\
\text { assaulted" by their husbands; } 12 \% \text { reported being } \\
\text { beaten within the last month (average } 2.65 \text { times); } \\
\text { ethnographic data indicate that prevalence rates are } \\
\text { "vastly under reported" }\end{array}$ \\
\hline India, 1990 (12) & $\begin{array}{l}50 \% \text { sample of all scheduled caste } \\
\text { households and } 50 \% \text { of non- } \\
\text { scheduled caste houses; } 109 \text { men and } \\
109 \text { women from village in Jullundur } \\
\text { District, Punjab }\end{array}$ & $\begin{array}{l}75 \% \text { of scheduled (lower) caste men admit beating } \\
\text { their wives; } 22 \% \text { of higher caste men admit to } \\
\text { beatings; } 75 \% \text { of scheduled caste wives report } \\
\text { being beaten "frequently" }\end{array}$ \\
\hline Malaysia, 1992 (13) & $\begin{array}{l}\text { national random sample of Peninsular } \\
\text { Malaysia; } 713 \text { women and } 508 \text { males } \\
\text { over } 15 \text { years old }\end{array}$ & $\begin{array}{l}39 \% \text { of women "physically beaten" by a partner in } \\
1989,15 \% \text { of adults consider wife beating } \\
\text { acceptable ( } 22 \% \text { of Malays) }\end{array}$ \\
\hline
\end{tabular}


Heise, L.

\begin{tabular}{l|l|l}
\hline Country, Year (ref. no.) & Sample Size and Type & Findings: Comments \\
\hline Colombia, 1992 (14) & $\begin{array}{l}\text { national random sample (part of } \\
\text { DHS); 3,272 urban and 2,118 rural } \\
\text { women }\end{array}$ & $\begin{array}{l}\text { 20\% physically and 33\% psychologically abused; } \\
10 \% \text { raped by husband }\end{array}$ \\
\hline Guatemala, 1990 (15) & $\begin{array}{l}\text { random sample of 1000 women in } \\
\text { Sacatepequez }\end{array}$ & $\begin{array}{l}49 \% \text { abused, 74\% by an intimate male partner; } \\
\text { includes physical, emotional and sexual abuse in } \\
\text { adulthood }\end{array}$ \\
\hline Mexico, 1993 (16) & $\begin{array}{l}\text { random household survey of women } \\
\text { on DIF (social welfare) register; 1163 } \\
\text { rural women and 427 urban women } \\
\text { in state of Jalisco }\end{array}$ & $\begin{array}{l}\text { 57\% of urban and 44\% of rural women had } \\
\text { experienced "interpersonal violence"; husband was } \\
\text { principal aggressor in more than 60\% of cases }\end{array}$ \\
\hline Ecuador, 1992 (17) & $\begin{array}{l}\text { convenience sample of Quito barrio; } \\
\text { 200 low income women }\end{array}$ & $\begin{array}{l}\text { 60\% had been "beaten" by a partner; 37\% of those } \\
\text { beaten were assaulted once a month or more }\end{array}$ \\
\hline Shile, 1993 (18) & $\begin{array}{l}\text { stratified random sample; 1,000 } \\
\text { women in Santiago aged 22-55 years } \\
\text { involved in a relationship of 2 years } \\
\text { or more }\end{array}$ & $\begin{array}{l}60 \% \text { abused by a male intimate; 26\% physically } \\
\text { abused (severe violence on CTS, i.e. more severe } \\
\text { than pushes, slaps or having object thrown at you); } \\
70 \% \text { of those abused are abused more than once a } \\
\text { year }\end{array}$ \\
\hline United States, 1986 (19) & $\begin{array}{l}\text { national probability sample of 2,143 } \\
\text { married or co-habitating couples }\end{array}$ & $\begin{array}{l}28 \% \text { report at least one episode of physical } \\
\text { violence; 11\% report abuse within last year }\end{array}$ \\
\hline Netherlands, 1989 (20) & $\begin{array}{l}\text { random sample of 1,016 women aged } \\
20-60 \text { years }\end{array}$ & $\begin{array}{l}21 \% \text { experienced physical violence in a } \\
\text { heterosexual relationship; half (11\%) experienced } \\
\text { severe, repeated violence }\end{array}$ \\
\hline Canada, 1994 (21) & $\begin{array}{l}\text { nationally representative sample of } \\
12,300 \text { women aged 18 and older }\end{array}$ & $\begin{array}{l}\text { 29\% of ever-married women report being } \\
\text { physically assaulted by an intimate partner since } \\
\text { the age of 16; 32\% of victims were assaulted more } \\
\text { than 11 times }\end{array}$ \\
\hline \hline
\end{tabular}

\section{Rape and Sexual Abuse}

Regrettably, statistics suggest that sexual coercion is a also a common reality in the lives of women and girls. Surveys from the United States reveal that between one in five and one in seven American women over the age of 18 has been the victim of a completed rape in her lifetime (Koss, 1993; Kilpatrick et al., 1992). International data also explode the myth of rape as a stranger perpetrated crime. Data from countries as diverse as Chile, Peru, Malaysia, Mexico, Panama, Papua New Guinea, and the United States all confirm that the majority of perpetrators (60-78 percent) are people known to the victim, and that a substantial subset of victims are very young girls (Heise et al., 1994).
Indeed, surveys reveal that young girl children are particularly at risk of sexual abuse. National random surveys from Barbados, Canada, the Netherlands, New Zealand, Norway and the United States reveal that 27 to 34 percent of women interviewed have been sexually abused during childhood (Handwerker, 1993; Haskell \& Randall, 1993; Draaijer, 1988; Martin et al., 1993; Schei, 1990; Lewis, 1986; Finkelhor et al., 1990). Lower but nonetheless significant rates of abuse have been measured in Great Britain (12 percent) (Baker et al., 1985) and Germany (16 percent) (Schotensack et al., 1992). Elsewhere, data from small-scale surveys give cause for concern. A study of 160 Egyptian girls and women revealed that sexual aggression by adult men toward young girls 
occurred in 45 percent of lower socioeconomic status (SES) families and 34 percent of higher SES families (Meursing et al., 1993).

Sexual abuse and rape survivors exhibit a variety of trauma-induced symptoms including sleep and eating disturbances, depression, feelings of humiliation, anger and self blame, fear of sex, and inability to concentrate (Koss, 1990). Survivors also run the risk of becoming pregnant or contracting STDs, including HIV. A rape crisis center in Bangkok, Thailand reports that 10 percent of their clients contract STDs as a result of rape and 15 to 18 percent become pregnant, a figure consistent with data from Mexico and Korea (Archavanitkui \& Pramualratana, 1990; COVAC, 1990; Shim, 1992). In countries where abortion is illegal or unavailable, victims often resort to illegal abortion, greatly increasing their chance of future infertility or even death.

\section{WHY FOCUS SPECIFICALLY ON VIOLENCE AGAINST WOMEN?}

Although men are victims of street violence, brawls, homicide, and crime, violence directed at women is a distinctly different phenomenon. Men tend to be attacked and killed by strangers or casual acquaintances, whereas women are most at risk at home from men whom they trust (Kellerman \& Mercy, 1992). Violence against women is grounded in power imbalances between men and women and is caused and perpetuated by factors different than violence against men. As such, it must be analyzed and addressed differently. While women are occasionally violent against intimates, research has shown that female violence is usually in self-defense and that it is women who suffer the bulk of injury (Dobash, 1992).

\section{IMPACT ON HEALTH CARE UTILIZATION}

In addition to injury, physical and sexual abuse provide the primary context for many other health problems. Victims of sexual abuse, rape and domestic violence are at increased risk of suicide, depression, drug and alcohol abuse, STDs, hypertension, chronic pelvic pain, irritable bowel syndrome, asthma, gynecological problems, and a variety of psychiatric disorders. Most victims of violence first seek medical care for the secondary sequelae of abuse, rather than for the initial abuse-related trauma (Heise et al., 1994; Koss \& Heslet, 1992).

Not surprisingly, victims of violence require a significant portion of scarce health resources. Studies reveal that 22 to 35 percent of women presenting with any complaint to U.S emergency rooms are there because of symptoms related to partner abuse (American Medical Association, 1992). Another study at a major U.S. Health Maintenance Organization (HMO), found that a history of rape or assault was a stronger predictor of physician visits and outpatient costs among women than were age or other health risks, such as smoking. Women who had been raped or assaulted had medical costs two and half times higher in the index year than nonvictimized women, even after controlling for other health, stress and demographic factors (Koss et al., 1991). A similar study by Felitti (1991) found that among women enrolled in an HMO plan, 22 percent of those who had a history of childhood molestation or rape had visited a physician 10 or more times a year compared to 6 percent of nonvictimized women. Such expenditures could be drastically reduced through preventive actions.

\section{IMPLICATIONS FOR INTERNATIONAL DEVELOPMENT}

Violence presents a powerful obstacle to achieving other goals high on the development agenda. Violence during pregnancy, for example, threatens the goal of "Safe Motherhood" for all women. Among 80 battered women seeking judicial intervention in San Jose, Costa Rica, 49 percent report being beaten during pregnancy (Ugalde, 1988). Battered women run twice the risk of miscarriage and four times the risk of having a low birth-weight infant (Stark et al., 1981; Bullock \& McFarlane, 1989). In some regions, violence also accounts for a sizeable portion of maternal mortality. In Matlab 
Thana, Bangladesh, intentional injury motivated by dowry disputes or stigma over rape and unwed pregnancy - accounted for 6 percent of all maternal deaths between 1976 and 1986 (Faveau \& Blanchet, 1989).

New evidence from the United States suggests that sexual abuse may serve as a direct break on socio-economic development by affecting a woman's educational and income level. A recent study shows that women who have been sexually abused during childhood achieve an annual income 3 to 20 percent lower than women who have not been abused depending on the type of abuse experienced and the number of perpetrators (after controlling for all known income factors) (Hyman, 1993). Violence has also been shown to interfere with women's participation in development projects. A study commissioned by UNIFEM/Mexico found that a primary reason women dropped out of projects was due to threats and violence by husbands who disapproved of their wive's empowerment (cited in Carrillo, 1992).

Likewise, fear of male violence can interfere with efforts to curb population growth and to control the spread of AIDS. According to research generated by USAID's Women and HIV project, women are frequently afraid to raise the issue of condom use for fear of abandonment, accusations of infidelity or physical reprisal (Rao Gupta, 1993). In some cultures, men assert that use of any birth control implies promiscuity or a women's desire to be unfaithful. In Kenya, women regularly forge their partner's signature on spousal consent forms for contraception rather than ask their partner's permission (Banwell, 1990). When family planning clinics in Ethiopia removed their requirement for spousal consent, clinic use rose 26 percent in just a few months (Cook \& Maine, 1987).

Through its impact on future sexual and drug using behavior, sexual abuse in childhood also appears to increase an individual's risk of contracting STDs and HIV in adulthood (Boyer \& Fine, 1992; Zierler et al., 1991; Finkelhor, 1987; Cassese, 1993; Paone \& Chavkin, 1993). In one study of 407 randomly selected men and women on the island of Barbados, sexual abuse in childhood emerged as the single most important determinant of high risk sexual activity during adolescence for both women and men (Handwerker, 1993). After controlling for a wide-range of socio-economic and homeenvironment variables (e.g. absent father), sexual abuse remains strongly linked to both the number of partners adolescents have and to their age at first intercourse. For men, physical, emotional and/or sexual abuse in childhood is also highly correlated with lack of condom use in adulthood, after controlling for many other variables.

Victimization may also lead indirectly to teen pregnancy through the unresolved feelings and behavior patterns that past abuse sets up. Some of the most commonly documented consequences of sexual abuse are early onset of sexual activity and an inability to distinguish sexual from affectionate behavior (Donaldson et al., 1989; Browne \&, 1986; Riggs et al., 1990). Frequently, the shame and stigma that abuse survivors experience leave them feeling vulnerable, unloved, and unable to say "no" to things they do not want to do such as having sex or using drugs. Moreover, as "damaged goods" they do not feel worthy or capable of undertaking self-protective behavior, such as contraception.

A recent study of adolescent mothers in Washington State found that young women who had been sexually abused during childhood began intercourse on average a year earlier than nonvictimized mothers, were more likely to have used drugs and alcohol and less likely to practice contraception. Only 28 percent of the victimized teens used birth control at first intercourse compared to 49 percent of their non-victimized peers (Boyer \& Fine, 1992). Another U.S. study confirmed that women survivors of childhood sexual abuse are nearly three times more likely than non-victimized youth to become pregnant before the age of 18 (Zierler et al., 1991).

\section{RESPONSE OF THE HEALTH SECTOR}

As the only public institution likely to interact with all women at some point in their 
life, the health system is particularly well placed to identify and refer victims of violence. This access is important because experience has shown that even in countries with a strong movement against violence, many women never choose to call the police or a crisis hotline, the two most widely developed sources for referral. Advocates in the U.S. state of Connecticut, for example, estimate that only 10 percent of battered women living there ever come in contact with the state's extensive network of legal advocates, shelters, and crisis centers, because the system relies primarily on the justice system and word of mouth to notify victims of available services (Heise \& Chapman, 1992). In politically repressive countries, the likelihood of the police serving as an adequate source of referral is even more unrealistic.

Women unwilling to seek help from the police or other governmental authorities, may nonetheless admit abuse when questioned gently, in private by a supportive health care provider. Experience has shown that most women will disclose abuse if asked in a nonjudgmental way. In fact, as Brazilian physician Dr. Ana Flavia d'Oliveira observed after implementing abuse screening in her prenatal clinic, "It was my impression that some women had been waiting their whole lives for someone to ask (Heise et al., 1994).

Providers can perform an important service simply by breaking the silence surrounding abuse and putting women in contact with individuals and groups better prepared to deal with her violence-related problems. Most major urban areas, even those in developing countries, now have at least a handful of NGOs providing services and support for victims that can serve as sites for referral. Even where no services exist, health professionals can emphasize that no one deserves to be beaten or to be blamed for being raped. Sympathetic treatment and a space to talk can greatly facilitate "healing."

Screening works best when done in conjunction with asking more general questions about the woman's sexual/gynecological history. A provider can create an opening for discussing marital rape, for example, by asking, "Does your husband/partner want sex more often than you?" This could be followed if appropriate with the question, "Has he ever pressured or forced you to have sex when you didn't want to?"

Likewise, issues of child sexual abuse can be broached by asking, "Did you have any upsetting sexual experiences in childhood or adolescence?" In settings where alcohol abuse is frequent, questions probing a partner's alcohol use can also provide an opening to discuss wife abuse or sexual coercion. Many women also respond well to direct questions asked in a non-judgmental way such as, "Has your partner or anyone else ever tried to physically harm you in any way?" It is best to avoid value-laden terms such as "incest" and "rape" and to ask questions a variety of ways to give women several opportunities to disclose.

Despite the potentially critical role of health care professionals, evidence indicates that few providers identify and respond appropriately to victims of abuse (Kurz, 1987). Health facilities can greatly enhance their staff's sensitivity to gender-based violence by introducing training and standardized protocols on how to respond to abuse. At the emergency department of the Medical College of Pennsylvania, for example, the percentage of female trauma patients found to be battered increased more than five-fold, from 5.6 percent to 30 percent after training and protocols were introduced (McCleer \& Anwar, 1989).

Training and protocols on violence are still rare, although initiatives are underway in the United States to encourage more active screening and referral of victims. In 1992, The U.S. Joint Commission on Hospital Accreditation passed new standards adding emergency room protocols and training on family violence to the list of criteria used to evaluate hospitals for accreditation (Heise \& Chapman, 1992). A new project sponsored by the Family Violence Prevention Fund in San Francisco and the Pennsylvania Coalition Against Domestic Violence, hopes to help institutionalize the new Hospital Accreditation standards by developing model protocols, 
training programs, and dissemination strategies that can be applied throughout the country.

Only a handful of programmes exist in Southern countries that focus on reforming the health care response to violence. Some pilot projects sponsored by the Pan American Health Organization are underway in Central America and isolated initiatives exist elsewhere (e.g. Profamilia in Bogata, Colombia and the Agisanang Domestic Abuse and Training project in Alexandra, South Africa) Most programs to date represent the untiring efforts of individual female health workers who felt compelled to respond to the prevalence of abuse among their clients.

\section{WHAT CAN BE DONE?}

Violence is an extremely complex phenomenon with deep roots in power imbalances between men and women, genderrole expectations, self esteem and social institutions. As such, it cannot be addressed without confronting the underlying cultural beliefs and social structures that perpetuate violence against women. In many societies women are defined as inferior and the right to dominate them is considered the essence of maleness itself. Confronting violence thus requires re-defining what it means to be male and what it means to be female. Research from the United States indicates that certain individual factors can increase the likelihood of violence on the part of any particular man including excessive alcohol use, a history of physical or sexual abuse within his own childhood, witnessing parental violence as a child and unemployment. But none of these factors accounts for why women are so systematically the targets. Only the pervasive existence of cultural, economic, and social systems that subordinate women can explain the overall pattern of abuse.

Nonetheless, cross-cultural ethnographic research does indicate that there are (or have been) isolated examples of societies where gender-based abuse does not exist (Sanday, 1981; Levinson, 1989; Counts et al., 1992). Such societies stand as proof that social relations can be organized in such a way as to minimize or eliminate violence against women. A look at these cultures suggests that they share the following key features:

- strong sanctions against interpersonal violence;

- community support for victims;

- flexible gender-roles for men and women;

- equality of decision making and resources in the family;

- a cultural ethos that condemns violence as a means to resolve conflict;

- female power and autonomy outside of the home;

Even where supportive social factors do not exist, experience has shown that strategic intervention on the part of the community, women's organizations, and the state, can save lives, reduce injury, and lessen the long term impact of victimization on women and their children.

Any response to violence must meet the immediate needs of victims while working to combat the attitudes, beliefs and social structures that encourage gender-based abuse. Important first steps include: 1) reforming laws that discriminate against women; 2) expanding legal, medical, psychological, and advocacy services for victims; 3 ) enacting and enforcing laws against battering, rape, and sexual abuse; 4) training professionals in how to identify and respond to abuse; 5) expanding the availability of shelters and safe home networks; 6) incorporating gender awareness training, parenting skills, and non-violent conflict resolution into family life curricula; 7) eliminating gratuitous violence from the media; and 8) ensuring alternatives for women by expanding access to low income housing, credit, child care, and divorce.

There is also urgent need for more and better data on the social and economic costs of violence, its impact on women's health and well-being, and the effectiveness of various interventions designed to curb abuse. Ongoing research efforts, such as focus groups and surveys being conducted on sexuality for the purposes of developing AIDS prevention programs, should use these opportunities to 
explore the role that violence and coercion plays in women's sexual and reproductive decision making.

\section{PROGRAM IMPLICATIONS}

It is time that governments and the international community recognize that women have a right to live free from physical and psychological abuse. The most important step forward is to support the nascent antiviolence initiatives already underway at both the government and non-governmental level. Much of the leadership to date has come from autonomous women's organizations who have fought tirelessly to open crisis centers, change laws, and challenge the cultural beliefs that perpetuate violence against women. These groups could easily be strengthened with only a minimal investment of resources.

A growing number of governments also have important new initiatives in need of support. Both the Brazilian and Colombian constitutions now have articles establishing the state's responsibility to combat family violence. Other governments - including Papua New Guinea, Chile, Canada, and Ecuador-have sponsored research, opened shelters or sponsored national media campaigns. The women's health community can play an important role in holding governments accountable to these commitments. At the recent World Conference for Human Rights held in Vienna Austria, a coalition of 950 women's organizations demanded and got official recognition for the first time of violence against women as an abuse of women's human rights. As the women's statement to the Government Assembly observed, "Putting violence high on the world agenda is not appeasing the interests of a 'special interest' group, it is restoring the birthright of half of humanity".

\section{RESUMO}

HEISE, L. Violência e Genêro: Uma Epidemia Global. Cad. Saúde Públ., Rio de Janeiro, 10 (suplemento 1): 135-145, 1994.

Violência baseada no gênero, incluindo seqüestros, violência doméstica, homicídios e abuso sexual, é problema profundo de saúde para a mulher em todo o mundo. Embora sendo uma causas significativa de morbimortalidade, a violência cintra as mulheres só recentemente foi reconhecido como objeto de Saúde Pública.

Este trabalho reune dados existentes sobre dimensões da violência contra as mulheres no mundo e revê a literatura sobre as consequiências das abusos sobre a saúde. Argumenta-se que o setor tem importante papel no combate à violência contra a mulher, através do desenvolvimento de pesquisas, notificação, organização de serviços de referência para as vítimas e para propostas de intervenção. Qualquer estratégia para confrontar a violência necessita ser dirigida para as raízes dos abusos, além, evidentemente, de atender às necessidades imediatas das vítimas. Isto significa desafiar atitudes e crenças sociais que fundamentam a violência dos homens contra as mulheres e criar formas de negociação do poder entre os gêneros, em todos os níveis da sociedade.

Palavras-Chave: Violência e Mulher; Saúde Reprodutiva; Abuso Sexual; Desenvolvimento Internacional

\section{REFERENCES}

ARCHAVANITKUI, K. \& PRAMUALRATANA, A., 1990. Factors Affecting Women's Health in Thailand. Paper presented at the Workshop on Women's Health in Southeast Asia. Population Council, Jakarta, October 29 to 31.

BAKER, A.; DUNCAN, W. \& DUNCAN, SP., 1985. Child sexual abuse: a study of prevalence in Great Britain. Child Abuse and Neglect, 9: 457-467.

BANWELL, S. S., 1990. Law, Status of Women and Family Planning in Sub-Saharan Africa: A Suggestion for Action. Nairobi: The Pathfinder Fund. (Mimeo.) 
BOYER, D. \& FINE, D., 1992. Sexual abuse as a factor in adolescent pregnancy and child maltreatment. Family Planning Perspectives, 24: 0410.

BROWNE, A. \& FINKELHOR, D., 1986. The impact of child sexual abuse: A review of the research. Psychological Bulletin, 99: 66-77.

BULLOCK, L. F. \& McFARLANE, J., 1989. The birth/weight battering connection. American Fournal of Nursing, 89: 1153-1155.

CARRILLO, R., 1992. Battered Dreams: Violence Against Women as an Obstacle to Development. New York: United Nations Fund for Women.

CASSESE, J., 1993. The invisible bridge: child sexual abuse and the risk of HIV infection in adulthood. SIECUS Report, 21: 01-07.

COOK, R. \& MAINE, D., 1987. Spousal Veto Over Family Planning Services. American fournal of Public Health, 77: 339-344.

COUNCIL ON SCIENTIFIC AFFAIRS/AMERICAN MEDICAL ASSOCIATION, 1992. Violence against women: relevance for medical practitioners. Fournal of the American Medical Association, 267: 3184-3189.

COUNTS, D.; BROWN, J. \& CAMPBELL, J., 1992. Sanctions and Sanctuary: Cultural Perspectives on the Beating of Wives. Boulder: Westview Press.

COVAC, 1990. Evaluacion de Proyecto para Educacion, Capacitacion, y Atencion a Mujeres y Menores de Edad en Materia de Violencia Sexual, Enero a Diciembre 1990. Mexico City: Asociacion Mexicana Contra la Violencia a las Mujeres. (Mimeo.)

DOBASH, R., 1992. The myth of sexual symmetry in marital violence. Social Problems, 39: 71-91.

DONALDSON, P. E.; WHALEN, M. H. \& ANASTAS, J. W., 1989. Teen pregnancy and sexual abuse: Exploring the connection. Smith College Studies in Social Work, 59: 289.

DRAAIJER, N., 1988. Intrafamiliar Sexual Abuse of Girls. The Hague: Minister of Social Affaires and Labour, Vrije Universiteit van Amsterdam.

FAUVEAU, V. \& BLANCHET, T., 1989. Deaths from injuries and induced abortion among rural Bangladeshi women. Social Science and Medicine, 29: 1121-1128.

FELITTI, V. J., 1991. Long-term medical consequences of incest, rape and molestation. Southern Medical fournal, 84: 328-331.

FINKELHOR, D., 1987. The sexual abuse of children: Current research reviewed. Psychiatric Annals, 17: 233.
FINKELHOR, D.; HOTALING, G.; LEWIS, I. A. \& SMITH, C., 1990. Sexual abuse in a national survey of adult men and women: Prevalence, characteristics and risk factors. Child Abuse and Neglect, 14: 19-28.

GRAITCER, P., 1994. Personal Communication. Atlanta, Georgia: Emory School of Public Health, February 12th.

HANDWERKER, P., 1993. Gender power differences between parents and high risk sexual behavior by their children: AIDS/STD risk factors extend to a prior generation. Fournal of Women's Health, 2: 301-309.

HASKELL, L. \& RANDALL, M., 1993. The Women' Safety Project: Summary of Key Statistical Findings. Ottawa: Canadian Panel on Violence against Women. (Mimeo.)

HEISE, L. \& CHAPMAN, J. R., 1992. Reflections on a movement: The U.S. battle against woman abuse. In: Freedom From Violence: Women's Strategies From Around the World (M. Schuler, ed.), pp. 257-294, Washington, D.C.: OEF International.

HEISE, L.; PITANGUY, A. \& GERMAINE, A., 1994. Violence Against Women: The Hidden Health Burden. Washington D.C.: The World Bank.

HYMAN, B., 1993. (Untitled). Ph.D. Dissertation, Waltham, Massachusetts: Heller School of Policy, Brandeis, University.

ISIS INTERNATIONAL, 1990. Violencia en Contra de La Mujer en America Latina y El Caribe: Directorio de programas. Santiago, Chile. (Mimeo.)

KELLERMANN, A. L. \& MERCY, J. A., 1992. Men, women, and murder: gender-specific differences in rates of fatal violence and victimization. The Fournal of Trauma, 33: 01-05.

KILPATRICK, D. G.; EDMUNDS, C. N. \& SEYMOUR, A. K., 1992. Rape in America: A Report to the Nation. Arlington: The National Victim Center.

KOSS, M., 1990. The women's mental health research agenda: violence against women. American Psychologist, 45: 374-380.

, 1993. Detecting the scope of rape: a review of prevalence research methods. Fournal of Interpersonal Violence, 8: 198-222.

KOSS, M. \& HESLET, L., 1992. Somatic consequences of violence against women. Archives of Family Medicine, 1: 53-59.

KOSS, M.; KOSS, P. \& WOODRUFF, J., 1991. Deleterious effects of criminal victimization on 
women's health and medical utilization. Archives of Internal Medicine, 151: 342-347.

KURZ, D., 1987. Emergency department response to battered women: resistance to medicalization. Social Problems, 34: 69-81.

LEWIS, I. A., 1986. Unpublished raw data from Los Angeles Times poll \#98, 1985. In: A Sourcebook on Child Sexual Abuse (D. Finkelhor, ed.), Newbury Park: Sage Publications.

LEVINSON, D., 1989. Violence in Cross-Cultural Perspective. Newbury Park: Sage Publishers.

MARTIN, J.; ANDERSON, J.; ROMANS, S.; MULLEN, P. \& O'SHEA, M., 1993. Asking about child sexual abuse: Methodological implications of a two stage survey. Child Abuse and Neglect, 17: 383-392.

McCLEER, S. V. \& ANWAR, R., 1989. A study of women presenting in an emergency department. American fournal of Public Health, 79: 65-67.

MEURSING, K.; COUTINHO, D.; DUBE, S.; MAHLANGU, R.; MOYO, M.; MPOFU, S.; MUNDY, V.; ONEKO, O.; SIBINDI, F. \& VOS, T., 1993. Child Sexual Abuse in Matabeleland. Bulawayo, Zimbabwe: Matabeleland Aids Council.

PAONE, D. \& CHAVKIN, W., 1993. From the private family domain to the public health forum: Sexual abuse, women and risk for HIV infection. SIECUS Report, 21: 13-16.

RAO GUPTA, G., 1993. Private Communication, April. Washington D.C.: Institute for Research on Women.

RIGGS, A.; ALARIO, A. J. \& McHORNEY, C., 1990. Health risk behaviors and attempted suicide in adolescents who report prior maltreatment. Fournal of Pediatrics, 116: 815-821.

SANDAY, P. R., 1981. The socio-cultural context of rape: A cross cultural study. Fournal of Social Issues, 37: 05-27.
SCHEI, B., 1990. Prevalence of sexual abuse history in a random sample of Norwegian women. Scandinavian Social Medicine, 18: 63.

SCHOTENSACK, K.; ELLIGER, T.; GROSS, A. \& NISSEN, G., 1992. Prevalence of sexual abuse of children in Germany. Acta Paedopsychiatrica, 55: 211.

SHIM, Y-H., 1992. Sexual Violence against Women in Korea: A Victimization Survey of Seoul Women. Paper presented at the Conference on International Perspectives: Crime, Justice and Public Order. St. Petersburg, Russia, June 21-27.

STARK, E.; FLITCRAFT, A.; ZUCKERMAN, B.; GREY, A.; ROBINSON, J. \& FRAZIER, W., 1981. Wife Abuse in the Medical Setting: An Introduction for Health Personnel. Monograph \#7, Washington, D.C.: Office of Domestic Violence.

TOFT, S. (Ed.), 1986. Domestic Violence in Papua New Guinea. Port Morseby, Papua New Guinea: Law Reform Commission Occasional. (Paper No. 19)

UGALDE, J. G., 1988. Sindrome de la mujer agredida. In: Mujer, no. 5, pp. 41-44, San Jose, Costa Rica: Cefemina.

WORLD BANK, 1993. The World Development Report 1993: Investing in Health. Washington, D.C.: World Bank.

ZIERLER, S.; FEINGOLD, L.; LAUFER, D.; VELENTGAS, P.; KANTROWITZ-GORDON, I. \& MAYER, K., 1991. Adult survivors of childhood sexual abuse and subsequent risk of HIV infection. American Fournal of Public Health, 81: 572-575. 